\title{
FSN-AQ 0009 \\ THE GROWTH PERFORMANCE AND SURVIVAL OF Clarias gariepinus FRY RAISED IN HOMESTEAD CONCRETE TANKS
}

\author{
OLUKUNLE OYIN \\ Department of Wildlife and Fisheries Management, University of Ibadan, Ibadan, Nigeria
}

Copyright 2010, Fisheries Society of Nigeria.

This paper was prepared for presentation at the $25^{\text {th }}$ Annual International Conference and Exhibition in Administrative Staff College of Nigeria (ASCON), Topo-Badagry, Lagos, Nigeria, $25^{\text {th }}-29^{\text {th }}$ October, 2010.

This paper was selected for presentation by an FISON Program Committee following review of information contained in an abstract submitted by the author(s). Contents of the paper, as presented, have not been reviewed by the Fisheries Society of Nigeria and are subject to correction by the author(s). The material, as presented, does not necessarily reflect any position of the The material, as presented, does not necessarily reflect any position of the FISON metings Theris of ish is conge of any part of this paper for com consent of the Fisheries Society of Nigena is prohibited. Permission to reproduce in print is restricted to an abstract of not more than 300 words; illustrations may not be copied. The abstract must contain conspicuous acknowledgement of where and by whom the paper was presented. Write Librarian, Fisheries Society of Nigeria (FISON), P. O. Box 2607 Apapa, Lagos.

\section{ABSTRACT}

Fertilizer application in earthen ponds has been used as a low-cost method of sustainable aquaculture production. This study was carried out to investigate the growth response of African Catfish fry Clarias gariepinus (Burchell, 1882) in three different culture media in Homestead concrete tanks.

The water in the control $\left(T_{1}\right)$ was not treated while $T_{2}$ and $T_{3}$ were treated with poultry droppings and soy bean milk filtrate respectively. Nine hundred (900) catfish fry weighing averagely 0.67 $0.69 \mathrm{~g}$ were randomly allocated per treatment. In each tank $(2 m \times 3 m \times 1.5 m)$ were suspended (3) net cages each (1m $x$ $1 \mathrm{~m} \times 1 \mathrm{~m})$. Each net cage had 100 fry. The fish in tank 1 (control treatment) were fed fish meal from the start at 5\% of their body weight four times daily while the other treatments were not fed at all for the first 7 days. Feeding with fishmeal commenced for treatments $T_{2}$ and $T_{3}$ on the next $8-14$ day. The weights of the feed were adjusted after weekly weighing Analyses of the culture media for phytoplankton composition and water quality parameters were done for all treatments at the end of the experiment. Tables 3 and 4. The culture media with poultry manure $\left(T_{2}\right)$ and soyabean filtrate $\left(T_{3}\right)$ were found to influence the quality and quantity of the plankton which in turn determined the growth and survival. Tables 1 and 2. However, the best weight increase was recorded in $T_{1}(2.33 \mathrm{~g})$ followed by $T_{3}(1.89 \mathrm{~g})$ and then $T_{2}(1.81 \mathrm{~g})$ had the lowest weight gain. The survival rates in all the treatments were high but was highest in $T_{3}$ (98\%) followed by $T_{2}$ (97\%) and $T_{1}(95 \%)$.

Dissolved oxygen, $\mathrm{pH}$ and temperature of culture media were variously affected by the treatments. The presence of zooplanktons (Rotifer and Daphnia species) invariably supported the highest survival $(98 \%)$ of the fry in treatment $T_{3}$. Treatment $\left.T_{3}(11.56 \pm 1.14) \times 10^{3}\right)$ generated higher concentrations of most of identified zooplanktons than treatments $T_{1}$ $\left.(5.39 \pm 0.73) \times 10^{3}\right)$ and $T_{2}(12.78 \pm 0.98)$ $\left.\times 10^{3}\right)$. These zooplanktons were absent in treatments $T_{1}$ and $T_{2}$.

The result indicated that fertilizing the culture medium using soybean milk filtrate or poultry droppings improved the growth and of C. gariepinus.

Keywords: Non-Conventional, Culturemedia, Growth/survival, Clarias gariepinus, Homestead Concrete tanks.

\section{INTRODUCTION}

Fertilizer application is considered a viable low cost method of sustainable aquaculture production. The success of any aquaculture venture will depend greatly on the quality of the medium in which the fish is raised, e.g. the concentration of natural and life micro-organism which constitute the first feed for the fry. Hence, the culture of natural food organisms in the medium which fish is raised becomes 
imperative if viable quantity of fingerlings is to be produced at minimum cost.

In tropical Africa and in Nigeria in particular the use of Artemia increases the cost of fingerling production (Omitoyin, 1999). Natural live food organisms occupy aquatic and semi-aquatic media habitats. They range from minute zoo and phytoplankton to insect larvae Adeniji et al. (1986); Ovie (1986). They have the advantages of assured freshness, supply of high quality proteins, and provision of vitamins, they can be produced in large quantities with predictable quality using manures, which are relatively cheap.

C. gariepinus is widely cultivated in Nigeria Olukunle (1996), Omitoyin (2007). The fish is omnivorous and can thus feed on both zoo and phytoplanktons Moses (1983). The manures used to fertilize the water (medium) in order to generate plankton are relatively cheap except for transportation cost. Poultry waste can be obtained free while soybean is cheaper than fishmeal. It is readily available in the local market. The use of homestead concrete tanks is fast becoming well known and should be encouraged for home bred fish in Nigeria, Olukunle, (1996).

Hence, it is therefore relevant to investigate the growth performance and survival of $C$. gariepinus fry raised in different culture media, with the aim of recommending the best to our local fish farmers reducing cost and boosting fingerling production.

\section{MATERIALS AND METHODS Rearing Tanks}

3 concrete tanks with dimension $3.0 \mathrm{~m} \mathrm{x}$ $2.0 \mathrm{~m} \times 1.5 \mathrm{~m}$ each were used. The tanks were impounded with water. 3 net cages of $1.0 \times 1.0 \times 1.0 \mathrm{~m}^{3}$ were suspended in each of the tanks. The net cages were anchored to the sides of the tanks and weighted down with heavy stones inserted in the pockets made at the lower corners of the net cages. This is to prevent drifting. Zippers were sewn at the top edges of the net cages to facilitate feeding and protection of the fingerlings from predation.

Each rearing tank was impounded with $6.0 \mathrm{~m}^{3}$ of water. Tanks 2 and 3 were fertilized with poultry waste and soybean milk filtrate respectively to enhance plankton production. Tank 1 was not fertilized and it served as the control.

Media Preparation: The poultry waste was collected from the University Teaching and Research Farm while the soybean was purchased from the local market both in Ibadan, Nigeria.

$420 \mathrm{~g}$ of poultry waste was weighed, stuffed in a jute bag and dropped into Tank 2. The recommended application followed the dosage of $60 \mathrm{~kg} / 10,000 \mathrm{~m}^{2} \mathrm{~kg}$ of soyabean, was weighed, soaked in water for 6 hours, and ground to a paste using 15 litres of water Adekoya et al. (2004). The resulting milk was filtered and the filtrate distributed evenly into the water in Tank 3. Tank 1 (Control) was impounded with water from the mains and no fertilizer was added.

\section{Experimental Fish}

900 hatchery-bred advanced fry (3 weeks) old of Clarias gariepinus, mean weight $0.67-0.97 \mathrm{~g}$ were randomly distributed into the net cages (Table 1). 300 fry per treatment with 100 fry/net cage. Each cage served as replicate. The experiment lasted 3 weeks.

\section{Experimental Feeding Trials}

Feeding of the experimental fish started the following day after stocking. Fish in Tank 1 were fed 5\% body weight of fish meal $(72 \% \mathrm{CP})$. Fish in Tanks 2 and 3 were allowed to graze on the generated natural micro-organisms for one week. No fishmeal was given.

Feeding of fry in tanks (2 and 3) with fishmeal commenced in the $2^{\text {nd }}$ week till the end of the experiment. The fish were fed 4 times per day. The initial and final weight of the fish per cage were taken 
using an electronic digital scale, SK 1000 to determine the weight gained over the experimental period (Table 1).

Water was allowed to flow freely in and out of the system at a minimum of 1 litre/min. Water samples were collected from the control and from each of the treatments at the end of the experiment. Table 4.0 shows the water quality parameters monitored which include dissolved oxygen, temperature, $\mathrm{pH}$. Plankton abundance was estimated from $0.1 \mathrm{ml}$ sub-sample using the electronic microscope and the plankton composition is as shown in Table $3 \mathrm{e}$. The survival rate of the fish in each unit was counted manually and subtracted from the number of fish stocked (Table 2.0)

\section{STATISTICAL ANALYSIS}

The analysis of variance (ANOVA) was used to test for significant differences between the treatment means, Sokal and Rohlf (1995).

\section{RESULTS AND DISCUSSION}

Fertilizer treatments used in this study increased plankton abundance. This agrees with the findings of Tidwell et al., (2000), Azim et al., (2001), Keshavanath et al., (2001) and Dharmaraj et al., (2002). Treatment 1 had the highest growth while Treatment 3 recorded the highest survival rate (Table 2.0). The quantity and quality of the planktons in treatment 3 (Table 3.0) encouraged the observed parameters.

Treatment $2\left(\mathrm{~T}_{2}\right)$, though had the highest plankton abundance $\left(12.78 \times 10^{3}\right)$, recorded a lower species diversity (4 zooplankters and 8 phytoplankters while Treatment $3\left(\mathrm{~T}_{3}\right)$ had 6 zooplankters and 9 phytoplankters. The zooplankton count for $\mathrm{T}_{2}\left(1.13 \times 10^{3}\right)$ was equally lower than $\mathrm{T}_{3}\left(2.73 \times 10^{3}\right)$. Specifically, Table 3.0 shows that treatment 3 induced higher production of zooplanktons of rotifers $\left(0.62 \times 10^{3}\right)$, and daphnia spp $\left(0.52 \times 10^{3}\right)$ which are absent in treatments 1 and 2 respectively. These zooplanktons are among the most preferred food for fry (Micha 1973, Bard, 1976, Heisig, 1979, Hirata, 1979, Bamimore, 1989). Hence, the observed higher survival of fry in the $\mathrm{T}_{3}(98 \%)$ as against $\mathrm{T}_{2}(87 \%)$ and $\mathrm{T}_{1}$ (97\%). All the three treatments had high survival levels but the significantly lower survival of fry in treatment $T_{2}$ can probably be ascribed to the significantly lower concentration of dissolved oxygen $(5.5 \pm 0.8 \mathrm{mg} / \mathrm{l})$ compared to that in $\mathrm{T}_{1}(7.5$ $\mathrm{x} 1.3 \mathrm{mg} / \mathrm{l})$ and $\mathrm{T}_{3}(6.4 \pm 0.8 \mathrm{mg} / \mathrm{l}) 9.50$. The mean temperature range of $25.1 \pm$ $1.1^{\circ} \mathrm{C}$ to $25.5 \pm 1.2^{\circ} \mathrm{C}$ and $\mathrm{pH}$ range of $6 . \overline{5}$ - 9 in all the treatments are within environmental parameters recommended and reported by Viveen et al. (1985), Body (1979) for tropical fish optimum growth and nutrient utilization.

This study shows that the use of organic fertilizers in enriching the media in which fry/fingerlings are raised are not only economical means of producing fish but also ensures higher survival rates. Soybean milk filtrate a non-convectional medium competed favourably with poultry droppings as well as the use of fishmeal as food for early stages of fish. A closer look at the three treatments of plankton composition in Table 3.0 shows that a composite combination of the two or the three treatments will probably generate $100 \%$ composition of both phyto and zooplanktons to meet the nutrient utilization needs of the fry, there is need to confirm this suggestion through experimentation. But for economic consideration, a combination of $\mathrm{T}_{2}$ and $\mathrm{T}_{3}$ will suffice. However, the addition of fishmeal $\left(T_{1}\right)$ can be done when financial consideration is not limiting after the third week. By this time some cost would have been saved and the fish farmer can be sure of a higher survival rate of fry/fingerlings.

Hence, fish farmers should be encouraged to raise fry/fingerling in medium fertilized using soyabean milk filtrate. 
Table 1.0: Mean Weight Gain (g) of $C$. gariepinus fry raised in experimental media

\begin{tabular}{|c|c|c|c|c|c|}
\hline \multirow[t]{2}{*}{ Treatments } & \multirow{2}{*}{$\begin{array}{l}\text { Initial Total } \\
\text { Weight }(\mathrm{g})\end{array}$} & \multirow{2}{*}{$\begin{array}{l}\text { Final Total } \\
\text { Weight }(\mathrm{g})\end{array}$} & \multirow{2}{*}{$\begin{array}{l}\text { Initial Average } \\
\text { Weight }(g)\end{array}$} & \multirow{2}{*}{$\begin{array}{c}\text { Final Average Weight } \\
\text { Weight }(\mathrm{g})\end{array}$} & \multirow{2}{*}{ gain $\%$} \\
\hline & & & & & \\
\hline $1 \mathrm{a}$ & 68.87 & 206.07 & 0.69 & 2.24 & 308.0 \\
\hline $1 b$ & 68.36 & 250.29 & 0.68 & 2.55 & 266.7 \\
\hline $1 \mathrm{c}$ & 69.18 & 216.60 & 0.69 & 2.28 & 302.6 \\
\hline $2 \mathrm{a}$ & 67.95 & 181.05 & 0.68 & 1.85 & 369.6 \\
\hline $2 b$ & 67.42 & 176.68 & 0.67 & 1.84 & 364.1 \\
\hline $2 \mathrm{c}$ & 66.90 & 167.46 & 0.67 & 1.73 & 289.3 \\
\hline $3 a$ & 67.84 & 191.97 & 0.68 & 1.98 & 343.4 \\
\hline $3 b$ & 68.33 & 179.94 & 0.68 & 1.82 & 393.6 \\
\hline $3 \mathrm{c}$ & 66.66 & 183.59 & 0.67 & 1.89 & 354.9 \\
\hline
\end{tabular}

Table 2.0: Survival of $C$. gariepinus fry per week (Nos)

\begin{tabular}{llll}
\hline Weeks & T1 & T2 & T3 \\
\hline 0 & 300 & 300 & 300 \\
1 & 296 & 296 & 298 \\
2 & 291 & 293 & 296 \\
3 & 285 & 291 & 293 \\
\hline
\end{tabular}

Table 3.0: Plankton Composition and Abundance $\left(\mathrm{x}^{3} 0^{3}\right)$ in Individual Treatment Tanks

\begin{tabular}{|c|c|c|c|c|c|}
\hline \multirow{2}{*}{\multicolumn{2}{|c|}{$\begin{array}{l}\text { Plankton } \\
\text { component }\end{array}$}} & \multirow[t]{2}{*}{ Affiliation } & \multirow{2}{*}{$\begin{array}{l}\text { Control Poultry } \\
\left(\mathrm{T}_{1}\right)\end{array}$} & \multicolumn{2}{|c|}{ Soy bean milk } \\
\hline & & & & droppings $\left(\mathrm{T}_{2}\right)$ & filtrate $\left(\mathrm{T}_{3}\right)$ \\
\hline Chaetoceros decipe & ens & $\mathrm{P}$ & $2.25+0.34$ & $2.50+0.20$ & $3.39+0.47$ \\
\hline Anabaena sp. & & $\mathrm{P}$ & - & - & $0.55 \pm 0.14$ \\
\hline Scenedesmus & & & & & \\
\hline accuminatus & & $\mathrm{P}$ & $1.17 \pm 0.19$ & $2.56+0.01$ & $0.20+0.02$ \\
\hline Cyclotella sp. & & $\mathrm{P}$ & - & - & $0.22 \pm 0.01$ \\
\hline Mycrocystis sp. & $\mathrm{P}$ & & - & $2.21 \pm 0.04$ & - \\
\hline Euglena viridis & $\mathrm{P}$ & & $0.56 \pm 0.14$ & $2.15 \pm 0.10$ & $0.52 \pm 0.01$ \\
\hline Oedogonium sp. & $\mathrm{P}$ & & - & $0.22 \pm 0.04$ & $1.02 \pm 0.01$ \\
\hline Melosira sp. & & $\mathrm{P}$ & $1.10 \pm 0.01$ & $-\quad-$ & $-\quad-$ \\
\hline Cosmarium sp. & $\mathrm{P}$ & & $0.18+0.01$ & $0.15+0.03$ & $0.24+0.02$ \\
\hline Oscillatoria sp. & $\mathrm{P}$ & & $0.13 \pm 0.04$ & $1.25 \pm 0.32$ & $1.87 \pm 0.11$ \\
\hline Pandorina sp. & & $\mathrm{P}$ & - & $0.51 \pm 0.10$ & $0.62 \pm 0.12$ \\
\hline Brachionus sp. & & & - & $0.15+0.02$ & $0.21+0.01$ \\
\hline Themocyclops sp. & $\mathrm{Z}$ & & - & $0.12 \pm 0.01$ & $0.49 \pm 0.03$ \\
\hline Lecane sp. & & $\mathrm{Z}$ & - & $0.11+0.01$ & $0.21+0.02$ \\
\hline Trichocerca & & & & & \\
\hline obtusidens & & $\mathrm{Z}$ & - & $0.75 \pm 0.10$ & $0.68+0.11$ \\
\hline Rotifer & & $\mathrm{Z}$ & - & - & $0.62+0.04$ \\
\hline Daphnia & & $\mathrm{Z}$ & - & - & $0.52+0.02$ \\
\hline TOTAL & & & $12.78 \pm$ & 11.56 & 1.14 \\
\hline
\end{tabular}

Table 4.0: Water Quality Parameters Measured (Mean $+S$ ) in Treatment Tanks

\begin{tabular}{|c|c|c|c|}
\hline Treatments & Temperatur & $\begin{array}{l}\text { d oxygenp } \\
(\mathrm{mg} / \mathrm{l})\end{array}$ & \\
\hline 1 & $25.5+1.0^{a}$ & $7.5 \pm 1.3^{\mathrm{a}}$ & $7.5+0.78^{a}$ \\
\hline 2 & $25.5+1.2^{\mathrm{a}}$ & $5.5 \pm 0.8^{a}$ & $7.9+0.87^{\mathrm{a}}$ \\
\hline 3 & $25.5 \pm 1.1^{\mathrm{a}}$ & $6.5 \pm 0.8^{a}$ & $7.2 \pm 0.81^{\mathrm{a}}$ \\
\hline
\end{tabular}

a,b,c - Values along the same row with different superscripts differ significantly from their respective mean values $(\mathrm{P}<0.05)$. 


\section{ACKNOWLEDGEMENT}

Our acknowledgement goes to Dr. Dayo Showunmi of Department of Zoology, University of Ibadan, Nigeria for analyzing the plankton samples at his own expense in terms of using his own reagents and time.

\section{REFERENCES}

Adekoya, B.O., Olunuga, O.A.,

Ayansanwo, T.O., Omoyinmi, G.A.K. (2004). Manual of the

Second Animal Fish Seminar and

Training Workshop held at Ogun

State Agricultural Development

Programme (OGADEP), Abeokuta on Nov. $10^{\text {th }} 2005$.

Adeniji ., (1986). Culture of natural fish food (Algal isolation and growth culture). Kainji Lake Res. Inst. Annual Report.

Azim, M.E., Wahab, M.A., Van Dam, A.A., Beveridge, M.C.M, Verdegerm, M.C.J. (2001). The potential of periphyton-based culture of two Indian major carps rhu Labeo rohita (Hamilton) and gonia Labeo gonius (Linnaeus). Aquaculture Research 32: 209216.

Bamimore, M.A. (1989). Performance of African catfish fry $C$. gariepinus raised on natural and artificial diets in hatchery. M.Phil. thesis Department of Wildlife and Fisheries Management, University of Ibadan, Ibadan.

Boyd, C.E. (1979). Water quality in warm water fish ponds. Auburn Uni., Agric. Experiment station, Auburn, Alabma. 35/9p.

Dharmarag; Manissery, J.K.; Keshavanath, P. (2002). Effect of a biodegradable substrate, sugarcan bagasse and supplemental feed on growth and production of fringelipped Peninsula carp, Labeo fimbriatus (Bloch). Acta lchthyologica et Piscatoria 32(2): $137-144$.
Heisig, G. (1979). Mass cultivation of daphnia pulex in ponds. The effect of fertilization, aeration and harvest on population development in cultivation of fry and its live food. European Mariculture Association. $534 \mathrm{p}$.

Hirata, H. (1979). Rotifer culture in Japan in cultivation of fish fingerlings and its live food. Euro Fisheries Soc. 534p.

Keshavanath, P.; Ganadhar, B.; Ramesh, T.J.; van Rooij, J.M.; Beveridge, M.C.M; Baird, D.J.; Verdegem, M.C.J.; Can Dam, A.A. (2001). Use of artificial substrates to enhance production of freshwater herbivorous fish in pond culture. Aquaculture Research 32: 189 197.

Micha, J.C. (1973). Etude des populations pscicoles de l'ubangui et tentatives de selection et d'adaptation de quelques especes a le'tang de piciculture. Centre Technique frostier Tropical, Nogent-surMarne, France.

Moses, B.S. (1983). Introduction to Tropical Fisheries. Ibadan University Press pp. 102-106.

Olukunle, O.A. (1996). Nutritional Potentials of Processed Sesame Seed Cake in the diets of Clarias gariepinus (Burchell 1822) Ph.D Thesis submitted to the Department of Wildlife and Fisheries Management, Faculty of Agric. and Forestry, University of Ibadan.

Omitoyin, B.O. (1999). Intensive fish farming: An Invited Tech. paper delivered at the Intensive Aquaculture Training Workshop organized by NIOMR V.I. Lagos, October, 1999. 9pp.

Omitoyin, B.O. (2007). Introduction to Fish Farming in Nigeria. Ibadan University Press Ibadan, Ibadan pp. 2-9.

Ovie, S.L. (1986). Fisheries Enterprises and Information, Brochure in commemoration of the $5^{\text {th }}$ Annual 
Conference of FISON pp. $71-76$. $\mathrm{Ph} . \mathrm{D}$ thesis Uni. Ibadan.

Sokal, R.R.; Rohlf, F.J. (1995). Biometry. The principles and practice of statistics in biological research. Third edition, W.H. Freeman and Company, New York.

Tidwell, J.H.; Coyle, S.D.; van Arnum, A.; Weibel, C. (2000). Production response of freshwater prawn, Macrobrachium rosenbergii to increasing amounts of artificial substrate in ponds. Journal of the World Aquaculture Society 31: $452-458$.

Viveen, W.J.A.R.; Richter, J.J.C.; Dordrot, P.G.; Jansen, J.A.L. and Huisman, E.A. (1985). Practical manual for the culture of African catfish, Clarias gariepinus. Directorate General for International Cooperation, The Hague, Netherlands. 